Вяра Ал. Найденова*

Бугарска, Пловдивски универзитет $\quad \begin{array}{r}811.163 .41 ' 373.611 ' 367.622 \\ 821.163 .41 .08-32 \text { Андрић И. }\end{array}$

„Пајсије Хиландарски”

Филолошки факултет

Катедра „Славистика”

\title{
СТИЛИСТИЧНАТА РОЛЯ НА МЕЖДУМЕТИЯТА В „ЖЕНСКИТЕ РАЗКАЗИ” НА АНДРИЧ ${ }^{1}$
}

Целта на настоящото изследване е да се открои стилистичната роля на междуметията в „Женскте разкази” на Иво Андрич вследствие на текстов анализ, систематизация на видовете междуметия от фонетично, синтагматично и семантично гледище и да се посочат техните конотации в процеса на обрисуването на характерите и събитията като една от специфичните черти на уникалния стил на този писател.

Ключови думи: стилистичната роля на междуметията, Женске приче, Андрич.

В лингвистичните характеристики на междуметието като лексикално-граматичен клас думи се проявяват значителни несъответствия по отношение на обема на понятието, следователно и на видовете и функциите на отделните междуметия. Освен това дефинициите по правило се основават на отсъствието на някакви признаци (фонетико-фонологична нестандартност, липса

\footnotetext{
* najvy@abv.bg

1 Настоящият текст е реализиран в рамките на проекта „Език и иконичност” към Фонд „Научни изследвания” съгласно договор № ДМ20/1/11.12.2017 г.
} 
на назоваваща функция, морфологична неизменяемост, синтактична независимост, функционално-прагматична несъчетаемост и др.). Въпреки комплексното прилагане на семантични, лексикално-граматични и синтактични критерии за дефиниране междуметието рязко се отличава от всички останали класове думи. Междуметията не представляват нито самостоятелна, нито служебна част на речта. Те се използват, за да придадат на устната или на писмената реч емоционалност и изразителност. Най-често те представляват спонтанен емоционален отклик на говорещото лице спрямо определена ситуация. Лингвистите предполагат, че междуметията са емоционални сигнали, „първични човешки думи”. Те са свързани с мимиката и жестовете, които съпровождат речта и също така изразяват физическо състояние или човешка реакция. Примарната функция на междуметията е да демонстрират непосредствено чувство (емоция). Реално човек изразява емоциите си чрез симптоматични рефлекторни неезикови вокализации, възгласи (понякога неартикулирани звуци), съпроводени по правило от съответните жестове и мимика. Във връзка основа на разработката е концепцията за двете различни реализации на коментирания знак (Амека, Шаронов и др.). От една страна е устната му форма - акустично явление с паралингвистичен характер, т.е. съпровождащо човешката реч, наричано вокален жест, а от друга - писмената му фиксация, т.е. междуметието като част на речта, като звукоподражателна дума на съответния вокален жест (Щерева 2009: 114). При проучването на междуметните единици трябва да се отчита този техен двойствен характер, при това във всеки един естествен език, тъй като вокалните жестове като цяло се смятат за универсални, имат надезиков характер при изразяването на някакво психо-физическо състояние или реакция и хората могат да ги разпознават независимо от културно-езиковата си принадлежност. 
В този план се реализира стилистичен ефект и експресивност в рамките на онова, което се нарича фонетичен символизъм - една от проявите на иконичността в езика, отражение на действителността в структурата на езика, на различни негови равнища. Материалната страна на всеки езиков знак - звуковата обвивка - разкрива широк простор пред фонетичния символизъм. Във всеки език съществуват думи или звукосъчетания, които за носителите на същия език дори чрез самото си звучене внушават определено значение (Кликовац 2004).

В настоящото изследване вниманието е насочено към междуметията и тяхната стилистична роля в „Женските разкази” на Иво Андрич като „минитропа” в могъщия поток на стила му като прозаик.

Една от основните формални характеристики на междуметието, подчертавана от лингвистите, е изключителната му фонологична структура и ярката му фонематична изразеност. Междуметието често демонстрира анормална фонемна съчетаемост, „срещат се такива фонемни съчетания, които са чужди на останалите части на речта, [...] както и специфични звукове извън фонемния инвентар на нашия език" (Ницолова 2008: 481). Като най-изразителни във фонетико-фонологичен план от всички междуметни единици с основание се сочат звукоподражателните. Те имитират главно неречеви прояви, възгласи, въздишки, стенания и подобни паралингвистични звукове, издавани от говорния апарат, придружаващи обикновено изразяването на определена емоция и по-рядко представянето на физиологично състояние. Тъй като тук се проучват писмено фиксирани междуметни единици, постановката е суперсегментните (прозодичните) характеристики на вокалните жестове да останат извън фокуса на изследването. Интонацията (мелодика, пауза, интензивност, темп), тонът, тембърът изпълняват неоспорима лингвистична роля при конкретната функционална употреба на 
междуметията. В писмения текст обаче това семантично уточняване се поема от стандартни лексеми, най-често глаголи и/или наречия (цъкам с език, викам уплашено, прошепвам, промърморвам и т.н.): Све мрмльајући, он је... Тек тада настаде на гумну вриска, па дуго запомагане... Цавише се и мушки гласови. Све је надвикивао глас неке старище која је лелекала кроз нос... (Андрич 2011: 15-16, Аникина времена); ... да не падне пред сельацима на колена и не јаукне... (пак там: 10); ... и како му глас пишти у ушима као бол (пак там: 98 - Ћоркан и Швабица); или: Озидо богме, ев' овакоооо... - удара Хубо дланом о длан, почграва на једној нози. Дућаниије пуикетају језиком, смију се (пак там: 85 - Љубав у касаби).

Ярко средство на фонетиката в стилистично отношение е звукоподражанието като частен случай на звукописа - употреба на звукосъчетания, наречени ономатопеи, наподобяващи звукове от неживата природа и обкръжаваща среда, от животинския свят или човешки глас. Според РЛТ (1980) така се имитират „звуковете от природата и човешкия живот, като най-често са свързани с движение". По същество ономатопеичните фонетични съчетания са на границата между междуметията и междуметно-глаголните форми. С тяхна помощ в художествения текст и в разговорната реч се постигат разнообразни слухови впечатления, обогатява се възприятието, стимулира се въображението за по-пълно разкриване на авторския замисъл. При съпоставката на голям брой несродни езици се установява, че ономатопеите и звукоподражателни елементи в речта във всички тях си приличат в структурен план (Воронин 1982). Определените значения се внушават чрез звукове от един и същи тип (напр. чрез експлозиви, фрикативи, сонора р, назали и др.), независимо от разглеждания език. Конкретно за сръбския език (CE) трябва да се изтъкне, че големи струпвания на съгласни са редки и нетипични, но ако се 
срещнат в даден контекст, те непременно са маркери на конотация, на стилистичен ефект. (Изключение прави сричкотворният сонор р в ролята му на основа на сричката). Не само ономатопеите, а и подобни конгломерати на субморфемно равнище, са силно натоварени с образност, синестезичност и символизират определено значение. Така се реализира асоциативният аспект на дадена фонема или група фонеми, които могат да залегнат дори и в основата на процеса на словообразуването, ако ще да е и само на фонетично символични или експресивни думи. (Кликовац 2004). Ономатопеичният потенциал на сонора р във всички езици означава звук, който се повтаря в бързи серии. В СЕ е и в ролята на вокал (сричкообразуващ), а доста често е комбиниран с още два-три консонанта. Разликата между първообразните междуметия и звукоподражанията се обуславя не толкова от произхода на звука (човек, природа), колкото от характера на категориалните признаци. При ономатопеите той е формален - целта е да се създаде копие на природен звук. Едно тиктак е достатъчно, за да се появи в съзнанието на възприемащия представа за звук от стрелки на часовник.

Разбира се, значението и конотациите на фонетичните символи с цялата им стилистична стойност се реализират на фона на внушенията от цялостното произведение, където ролята на контекста е най-голяма. Т.е. акустичната страна не е действена само по отношение на парадигматичния план, а и в синтагматичен план, което е типично за текст от художествения стил и тук конкретно - в „Женските разкази” на Иво Андрич:

- Ти-ридам, ти-ридам, тиридиридирдири диридиридам, тиридам!...

- Ти-ридам, ти-ридам... хај, хај, хајха́j! (Андрич 2011: 104-105), където междуметията, имитиращи мелодията на популярна песен, на фона на жестовете, движенията и изражението на Чоркан от едноименния разказ са ярки 
щрихи, обрисуващи душевното му състояние - смесица от самоирония, отчаяние и изоставеност, страх, самота и някакво неистово опиянение, лудешка радост, откъсната от реалността, в желанието му да задържи в паметта си прекрасно изживяване от миналото и едновременно да забрави причиненото му страдание: „Нешто му очи залијева, као сузе, као веселье. Све је непромјенльиво и истинско на свом мјесту. Све му у ушима шуми и све му се у очима слијева и таласа" (пак там).

Първообразни (същински, примарни, първични) са онези междуметия, които образуват ядрото и представляват прототип на лексикално-семантичната категория междуметие. Повечето изследователи ги характеризират като много стари, а произходът им трудно би могъл да се установи. Те са морфологически неразчленими и нямат ясна етимологична връзка с другите части на речта. Важната им роля, особено в разговорната реч, ерго - във фикционалното ѝ представяне в текстовете на разказите на Иво Андрич, се състои и в това, че засилват комуникативния ефект на речта и спомагат за интензифицирането на емоционалната и експресивната функция на езика. Същинските емоционални възгласи са непреднамерени. Имат причина (мотив, стимул), но не и цел. Става дума за неконтролируеми речеви действия, които обаче притежават комуникативна стойност и често заменят в речта пълноценни изказвания: Јаооох!; Аман! (Ћоркан и Швабица); Исусе! Исусе! Ааах!... (Чудо у Олову).

При междуметия, образувани от глагол, най-често функционират императивните форми на глаголите. Благодарение на модалния елемент в семантиката на императива същинската му функция се модифицира и той се реализира като комуникативно средство, чрез което се установява пряк контакт или се поддържа разговорът. В резултат на това понятийният компонент в семантиката на тези форми отстъпва и се неутрализира в различна 
степен. Глаголите, от които се образуват „императивни” междуметия, са свързани обикновено със слуха, зрението, движението, мисленето и речта: гле!, види-види, погледај, чекај, слушај, стој, бриши. При тези примери степента на десемантизация е най-силна. В CE се наблюдава и процес, при който към междуметие се добавят глаголни окончания: хајде! хајдемо! хајдете!, а понякога в речта се стига до съвсем опростеното, непрецизно и разговорно произнасяне: 'ајмо! 'ајmе! При междуметията, образувани от наречие, от типа: тешко, благо задължително присъстват и пълните форми на личните местоимения в дателен падеж мени, теби, юему, юој, нама, вама, ғима. Степента на десемантизация е най-ниска при тези форми и би следвало да се приемат като наречия, употребени междуметно. Най-много вторични междуметия са образувани от съществителни имена (звателни форми като боже!) и от глаголи (императивни форми като гле!).

Още един характерен ефект постига Андрич с употребата на подобни звукоподражания и контактни междуметия. Използвайки силната им експресивност, авторът успява достоверно и живо да имитира разговорния, фамилиарния и просторечния говор, където те са с висока фреквентност. В стила на този писател пряката реч е в малко количество, дори е оскъдна. Но именно поради това присъствието ѝ в разглежданите разкази е толкова стилистично значещо, натоварено с допълнителни смислови и емоционални нюанси за характеризиране на героите и събитията. На фона на прозаичното изложение, типично за стила на нобеловия лауреат, което може да се оприличи на непристъпни яки крепостни стени или стабилен каменен мост, пряката реч е проявата на човешкото. Междуметията пък са стенанията на душата, вградена в тази монолитна постройка. Доста силни чувства и душевни вълнения, вариращи от съмнение, колебание, отчаяние, изненада, страх, възмущение, предизвикател- 
ност, гордост, подигравка, протест, радост, възторг, въ3хищение са маркирани само от такива съвкупности от фонеми, почти задължително съпроводени с възклицателен знак във всички разглеждани творби: $e$; ооо!; ех!; а!; ама; их?!; јаооох!; хај, хај, хај, хај!; еј-хеј!; Ааах!...; Ако!; амаааах!; Ex, uma ћеш, де!; сиктер! (тур.); аман, амааан (тур); ешкуна! (наздраве - тур.); селам (поздрав - тур.-араб.), белћим (тур). В сръбския език съществуват множество възклицания с различна семантика, употребявани в конкретни ситуации и с по-установена смислова основа: ujy!; jy!; jao!; jaoj! (при болка или неочаквана неприятна ситуация); ja; jec; да, да; jecm; jecme, jecme (за утвърждение); хм (съмнение, недоверие, неопределеност); $n .$. $n n . . . n$ (заплюване против уроки), e, e, e, na...; yхa!; ехе!; ax, да!; ама, a!; a-a-a?; yx; е na; ayx!; axa, axa...?; но!; бре!; охо! ама...; yø!; nøyj! (за отвращение), доле!; болан... бона (съчувствие, гальовност, фамилиарност); Уa!; Уу! (непреводими звукове с неодобрителна конотация); Куш! (за прогонване на животно); Мup! Пст! (за въдворяване на ред и тишина) и други възгласи въз основа на комбинации от фонеми. Понякога възклицанията, предимно на женски персонажи, са съпроводени с десемантизирани обръщения към бога: забога!; побогу; дабоме; дабогда; богме; богами; господе боже!; боже мој!; Исусе!; ох (о), боже!; вала(ј), валахи; дина ти! (тур. - РМС); Амин, Боже, велики и једини. Амин. Амин. (Андрич 2011: 39, Аникина времена), „Бог Саваот!”, „Богородииа пречиста!” (пак там: 164, Јелена, жена које нема).

Така че никак не случайно, а именно заради тяхната изразителност междуметията са наречени „звукови жестове" (Попов 2001: 98). Семиотичната същност на първообразните междуметия се изразява в тяхната иконичност. Подобно на вокалните жестове те също са мотивирани знаци, но имат изкуствен характер. Това са звукоподражания - образи на вокален жест. Образите 
винаги са маркирани със семантична дисфункция, която се изразява в полисемантичност на лексикалните единици. Иконичността е основана на подобие между знака и обекта с известна степен на условност. Това обяснява факта, че, поставени в конретен ситуативно-речев контекст, иконичните знаци могат да функционират на надезиково ниво и да бъдат разбираеми за хора с различна лингвокултурна идентичност (Щерева 2009: www).

С лаконични щрихи, каквито са междуметията не само от сръбския език, но и произхождащи от арабски и турски език, Андрич дискретно, но пълноценно пресъздава в творчеството си специфичната среда, времепространството и поднебието с разнообразието от националности, вероизповедания и наречия в Босна. В разказа „Времената на Аника” междуметие или частица, включени в реплика на главната героиня - скъперница на думи, но красноречива с красотата и женствеността си, в момент, когато е поставена пред екзистенциален избор - получава огромна стилистична „тежест”: Ево, nа уби'! ... Убu', де! (Андрич 2011: 62). Кратката и драматична фраза лаконично обрисува душевните терзания на самата Аника, съмняваща се в своя житейски избор, но все така изпълнена с гордост и пренебрежение към условностите, с предизвикателна храброст на иначе нежна жена, дръзнала да се противопостави на ориенталско-патриархалните нрави със свободолюбието си, с което предизвиква неодобрението, омразата и отмъстителността на сивото и безлично обкръжение в града.

В СЕ се използва „овај” (показателно местоимение м.р., ед.ч. за обект в най-голяма близост до говорещия) като израз на колебание и несигурност, като хезитативна паразитна дума за запълване на пауза в потока на речта (маркирана от многоточието). В подобни случаи тази дума, напълно десемантизирана, може да се приравни до междуметие или фонетично съчетание: „Од чега сам ја-а- 
a-a?! / Од слонове... овај, од... (Андрич 2011: 175, Жена од слонове кости), или „Толика вубав и дослук, па ти мени да речеш, овај..” (пак там: 100, Ћоркан и Швабица). Отново авторът скъпернически и лаконично, но блестящо пресъздава стихията на разговорния език и пресъздава определени душевни състояния чрез подобни езикови средства.

В разказа „Елена, жената, която не съществува” съществителни имена, някои от които в съчетание с прилагателни, или пък наречия, в стилистичната им транспозиция конкретно и единствено в този текст могат да бъдат трактувани и като междуметия на фона на разиграваната сцена и имайки предвид интонацията на търговеца: „При том је челичним гласом изговарао име животине на турском, грчком или француском језику, одсечно и пословно. „Визон”, „визон сафир”, „визон саго”, „индијско јагне”, „астрахан”, „пантера”, „хермелин”, „самуровина”. А уз свако од тих имена додавао је једну једину реч: „бино!”, „отмено!”, „модерно!”, „ретко!”(Андрич 2011: 164), където лексемите всъщност се десемантизират и придобиват доминиращата характеристика на възторжени възгласи, прославящи качествата на предлаганите кожени палта.

Един от най-характерните белези, присъщи на голяма част от междуметията, е способността им да се мултиплицират. Обикновено афинитет към мултиплициране проявяват емоционално-експресивните с цел интензификация на изразяваната емоция. Въпреки възможността за n-броя повторения примерите с редупликация над три пъти рязко намаляват. Най-често изследователите се натъкват на дву- и тричленни структури, напр. ax-ax/ ej-хеј / + емфатично удължаване и специфична интонация: Ej-хеј, нигдје ја пријатеља немам! (Андрич 2011: 95, Ћоркан и Швабица) или Охохооо... (89 - Љубав у касаби). Освен засилена емоционално-експресивна натовареност мултиплицирането при междуметията би 
могло да има и чисто дистинктивен характер: $x a$ (израз на пренебрежение) / $x a-x a$; $x a-x a-x a$ (смях). Част от звукоподражателните междуметия пък се реализират като лексеми само в мултиплицирана форма. Напр. кис-кис

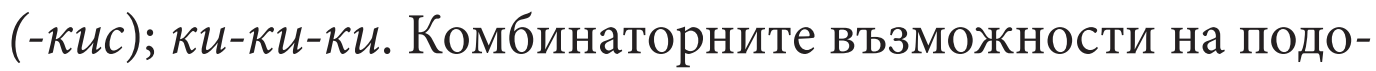
бен тип единици са силно ограничени. Най-често обаче моносъчетаемите (моноколокабилните) междуметия са с хетерогенна структура: тик-так, хоо-рук и др.

Лексикалната синтагматика на междуметията е пряко свързана с функционално-семантичните им характеристики. Проучването на емпиричния материал очертава конкретна тенденция към съчетаване на единици от един и същи вид, при това главно в ядрото на междуметната лексика. Емоционално-експресивните междуметия се комбинират в строго определен ред обикновено до трикомпонентни структури. Изключения съществуват главно в художествената литература с оглед на постигане на конкретен стилистичен ефект. Схематично комбинацията между първообразни и производни емоционално-експресивни единици могат да се представят по следния начин: ax, боже; о, господе, боже (мој)!

Външната синтагматика на междуметията също има стилистична роля - за привличане на вниманието на събеседника или подсилване на впечатлението при изричане на молба или заповед. След емоционално-експресивните или контактовите междуметия в обичайната им начална позиция най-често се появява звателна форма на съществително: $\underline{A}$, Ћоркане!; $E_{2}$ фала ти, газда Станоје... (Андрич 2011: 97; 100). Глаголни форми в повелителното наклонение или изрази със значение на молба/заповед също са сред най-близкото лексикално обкръжение на междуметията: Шути, болан! (пак там: 100); Их, нека ме, бона, овде (36 - Аникина времена). Очевидно е сходството във функционално-семантично и комуникативно-прагматично отношение между зва- 
телни и повелителни форми, от една страна, и някои междуметия, от друга. Това вероятно, съчетано с формалната позиционна близост, обяснява защо именно тези форми най-често и най-лесно губят лексикалното си значение на автосемантични думи и започват да изразяват непосредствена емоционална реакция или да изпълняват контактова функция, т.е. транспонират се в производни междуметия (боже, мајко, види(ш), слушај, гледај).

В „Женските разкази” на Иво Андрич благодарение на стилистичните средства от фонетичното равнище и най-вече на междуметията, адекватно употребени, със силна стилистична натовареност, „ударност” и „единичност, сингуларност”, у читателя се предизвиква емоционално-психологическо впечатление и се добавят филигранни щрихи към представяните драматични събития и проникновени човешки чувства. Възклицанията, обръщенията и ономатопеите в разглежданите текстове, макар да са „минитропи”, успешно спомагат за реализацията на авторовите интенции и подсилват драматизма на описваните характери и събития. Като стилистично релевантни компоненти с голяма креативност, вплетени в специфичния Андричев стил, съпътстващите звукове без графическа стойност и разнообразните просторечни междуметни прояви от всички езикови равнища на фона на оскъдните редове диалог, са лаконични, но значими допълнения при изграждане образите на героите, изживяващи опустошителни страсти и житейски потрес. В разглежданите творби на сръбския нобелист конотативната натовареност на междуметията се засилва в комбинация и интеграция с езиковите единици от всички равнища, което обогатява конкретния контекст смислово и емоционално, изтъкват се определени текстови цялости, създават се нови и нови нюанси в значението. Въздействието на тези разкази се постига чрез ефекти или образи в съответствие с художествените задачи на Иво Андрич: да 
разкаже за едно загадъчно и омагьосано време и място, за истински и легендарни събития, равни по дълбочината на човешкото страдание с древногръцките трагедии.

\section{Литература}

Андрич 2011: И. Андрић, Женске приче, Београд: Дерета.

РЛТ 1980: Речник на литературните термини, София: Наука и изкуство.

Воронин 1982: С. В. Воронин, Основы фоносемантики, Ленинград: Ленинградский университет.

Кликовац 2004: Д. Кликовац, Метафоре у мишльеюу и језику. Београд: Библиотека XX век, 139.

Ницолова 2008: Р. Ницолова, Междуметията - заварените деца на граматиката, $B$ търсене на смисъла и инварианта. София: УИ „Св. Климент Охридски”.

РМС 1967: Речник српскохрватскога књижевног језика Матице Српске, т. 1. Нови Сад-Загреб.

Попов 2001: Д. Попов, Стилистика, Шумен: УИ „Епископ Константин Преславски".

Томова 2016: К. Томова, Междуметията в системата на българския и чешкия език, дисертация, Пловдив: ПУ „П. Хилендарски”.

Шаронов 2002: Шаронов, И. А. Толкование эмоциональных междометий как знаков восприятия, Russian Lingustics, № $26,235-254$.

Щерева 2009: К. Щерева, Парадоксът на иконичния знак или проблемът за хронологичния приоритет при звукоподражанията, LiterNet, 01.05.2009, № 5 (114) // http://liternet.bg/ publish23/k_shtereva. 
Вјара Ал. Најденова

\section{СТИЛСКА УЛОГА УЗВИКА У ЖЕНСКИМ ПРИЧАМА ИВЕ АНДРИЋА}

Стилска улога узвика и њихове разноврсне конотација у књизи „Женске приче” И. Андрића и уопште у његовом јединственом стилу прозног наратива су откривена након анализе текста прича, систематицазије врста узвика са фонетске, синтагматске и семантичке тачке гледишта.

Примарна функција узвика то је, користећи нејезичке вокализације, усклика и понекад неартикулисаних звукова у комбинацији са гестовима и изразима лица, изражавати емоције. С једне стране, они имају усмени облик, они су акустични феномен паралингвистичкога карактера (вокални гест), с друге стране - могу се писмено фиксирати као реч одговарајућега вокалнога геста. Стилски ефект и експресивност реализују се у оквиру „фонетског симболизма”, једне од манифестација иконичности у језику.

Срж лексичко-семантичке категорије узвика то су примарни узвици, чија је стилистичка улога интензификација комуникативног ефекта и емоционално-експресивног утицаја. Највећи број секундарних узвика се формира од именица (у облику Вокатива: Боже!) и од глагола (у императивном облику: гле!). Захваљујући томе, Андрић верно пресликава разговорни језик, где је њихова фреквентност велика, а такође кратко, али са јаким стваралачким утицајем допуњује карактеризацију ликова.

У стилу писца, директни говор је лаконски. Због тога је његово присуство толико значајно као стилска појава. Свака реч је испуњена додатним семантичним и емоционалним нијансама. Уметање, узвикивање и ономатопеја у ретким и кратким дијалозима, још више се јасно манифестују као стилски релевантне компоненте са великим креативним потенцијалом. Они су важни елементи у стилу нарације нобеловца Андрића, када приказује ликове, који трпе егзистенцијалне патње, разарајуће олује страсти и тегобе једноличне свакодневнице равне оним у древногрчким трагедијама.

Къучне речи: стилска улога узвика, Андрић, Женске приче 